details of the prineipal river basins. Another excellent point is the inclusion of a short discussion on inward and outward radiation. This subject ought not to be neglected in the discussion of any climate and least of all in the case of one referring to a country placed in such high latitudes as to show very great seasonal contrasts. In the extreme north of Sweden (lat. $69^{\circ}$ ) the sun is never less than $2^{\circ}$ below the horizon in the middle of the winter. Even in the south (lat. 56 $6^{\circ}$ ) the solar elevation at that season does not exceed $10 \frac{1}{2}^{\circ}$. In the middle of the summer, on the other hand, a large part of Sweden enjoys perpetual daylight. In the early summer, the average amount of cloud in the eastern lowlands falls below anything known in Great Britain and, in the islands off the east coast, reaches the low figure of 40 per cent in June. When the long day is considered in relation to these facts, no surprise will be caused by the statement (p. 12) that the mean duration of sunshine at Jokkmokk (lat. $66^{\circ} 36^{\prime}$ ) in June exceeds that of Madrid or Rome in the same month. In sympathy with the large annual variation of solar radiation, temperature shows great seasonal contrasts. At Karesuands (lat. $68^{\circ} 27^{\prime}$ ) the mean temperature for
July is about $28^{\circ} \mathrm{C}$. $\left(50^{\circ} \mathrm{F}\right.$.) higher than that for January.

Figs. 6 and 7 are among the most interesting in the book. The former gives graphs of the radiation received at the outer limit of the atmosphere in each month in latitudes $55^{\circ}, 60^{\circ}, 65^{\circ}$, and $70^{\circ}$, similar graphs showing how much of this reaches the earth's surface when the sky is free from cloud; a graph of the radiation actually received at Stockholm, taking into consideration the amount of cloud, is also shown. In Fig. 7 this graph of inward radiation at the ground for Stockholm is compared with that of outward radiation at the same place. The outward radiation has, of course, much the smaller annual variation. The comparison shows that from the beginning of October to the end of March the outward exceeds the inward radiation, and that the reverse is true during the rest of the year. On the whole year it would appear that there is a gain. The reader may be referred to recent papers by Dr. G. C. Simpson, Director of the Meteorological Office of Great Britain, for a more general discussion of this subject, which is by no means free from pitfalls.

\title{
Afforestation Programmes of the New Zealand Forest Department.
}

$\mathrm{I}^{\mathrm{s}}$ a recent number of NATURE (Feb. 14, p. 255) attention was directed to the organisation known as the New Zealand Timber Growers' Association, of New Zealand. This body consists of a series of independent private companies engaged in afforestation work as a purely commercial proposition, with funds subscribed by the public on ordinary shareissue terms. These companies have no connexion with the official New Zealand Forest Department; but it is already apparent that they will eventually own by far the largest area of artificially formed plantations in the islands. Contrasted with the operations of these companies, already discussed in the note referred to, the Annual Report of the Director of the N.Z. State Forest presents the Government forestry position, which is equally satisfactory. On the subject of afforestation work, the Report states: "New Zealand possesses the largest area of State-owned and State-planted forests in the Empire. The State-owned indigenous forests as at March 31st, 1930, consisted of over 7 million acres. The State Softwood Plantations, in round figures, at the same date, covered 253,600 acres. The total area planted during the 12 months prior to the date mentioned was 56,630 acres. For the current year a further 54,629 acres was programmed for, which would bring the total of New Zealand's State Softwood Plantations at this present date to a figure approximating 308,000 acres. In the year ended March 31st, 1929, the State planted 60,635 acres altogether.'

A contrast is then made with similar work in Great Britain. The Forestry Commission in England, it is pointed out, planted to the end of $1929,140,000$ acres of softwoods, "while the planting programme is 23,000 acres per annum; so that New Zealand is well ahead of the Mother Country, and furthermore would be justified at the present time in claiming world-leadership in annual softwood plantings under the State". Full credit may be given to the New Zealand authorities for the efficient manner in which they are dealing with this problem; but any attempt at rivalry in the rate of afforestation or in programmes with that sole end in view between the Dominion and Great Britain is most strongly to be deprecated. Many things must govern annual planting programmes; and the delicate and important operations of thinning, once the young woods have reached the size for these operations, annually increase in amount and demand the closest attention. Too often in the past have annual afforestation programmes been pressed on, to the neglect of the necessary thinning work in the young created woods, for which either the funds or the necessary labour were deficient or absent.

The commercial planting companies have planted a total area of about 220,000 acres, the species being Pinus insignis, redwoods, Pinus ponderosa, and poplar. Thus State plantings plus the planting of these afforestation companies now total approximately 500,000 acres, last year's total plantings being somewhere in the region of 100,000 acres.

Since the commercial planting companies are wholeheartedly devoting themselves to new afforestation work, it will be hoped that the Government Department is not losing sight of the important indigenous forests. There may be quite valid reasons for embarking upon a large programme of plantations of exotics in a country - in parts of our Empire we know that such valid reasons exist-but all experienced foresters hold strongly to the belief that in the long run few exotic plantations can compete in value with the indigenous forest of a country.

It is a well-established fact that the planting of large blocks of exotics, often as pure woods, leads to the danger of attacks of pests, whether insect or fungus. This factor has not been overlooked in New Zealand. Research work in forest biology has been placed on a good basis by the linking up of the research forces of the State Forest Service, the Department of Scientific and Industrial Research, and the New Zealand Timber Growers' Association, under the direction of Dr. David Miller, with whom is associated Dr. Marsden. A number of research stations under the ægis of the State Forest Service have been established throughout the Dominion, the forestry schools of the University of New Zealand making contributions to the scientific side of afforestation. Amongst studies on the commercial side of forestry, investigations into the strength of structural timbers are being carried out, and an extensive economic pulpwood survey is in progress with the object of establishing pulp and paper mills in promising localities.

It is of interest to note that Australia continues to absorb practically the whole of the timber exports of New Zealand; but, the Report says, "enquiries from the United Kingdom continue to increase". 